\title{
Lumen
}

Selected Proceedings from the Canadian Society for Eighteenth-Century Studies

\section{The Uses of Empiricism: Ernst Christian Trapp and the Tribulations of an Educational Reformer in Eighteenth-Century Germany}

\section{Norman R. Diffey}

Volume 16, 1997

Freedom and Boundaries

Émancipation et frontières

URI : https://id.erudit.org/iderudit/1012446ar

DOI : https://doi.org/10.7202/1012446ar

Aller au sommaire du numéro

Éditeur(s)

Canadian Society for Eighteenth-Century Studies / Société canadienne d'étude du dix-huitième siècle

ISSN

1209-3696 (imprimé)

1927-8284 (numérique)

Découvrir la revue

Citer cet article

Diffey, N. R. (1997). The Uses of Empiricism: Ernst Christian Trapp and the Tribulations of an Educational Reformer in Eighteenth-Century Germany. Lumen, 16, 147-161. https://doi.org/10.7202/1012446ar 


\section{The Uses of Empiricism: Ernst Christian Trapp and the Tribulations of an Educational Reformer in Eighteenth-Century Germany}

Education provided a rich field of inquiry for the Enlightenment. The philosophical movement, whose crowning achievement was a monumental Encyclopédie, was in a sense a pedagogical movement, dedicated to the moral and social advancement of a 'perfectible' humanity through the acquisition of knowledge and virtue. It is hardly surprising, then, that in the course of the eighteenth century the reform of education and its institutions should assume a symbiotic role in the larger reform of society. The process of understanding and politicizing this relationship was a gradual one, which involved the crossing of much ground in the seventy years that separated the century's two most influential educational treatises. There is more than a temporal gulf between Locke's socially conservative Thoughts Concerning Education (1693), in which raw youth acquires the degree of 'Virtue, Wisdom, Breeding and Learning'(Thoughts 194) appropriate to its place in an established order, and the brazen individualism of Rousseau's Émile (1762), 'the book that was to change Western educational thought' (Bowen 183). Rousseau's belief that the forms and content of education are those required, not by society, but by nature, more precisely the innately 'good' nature of the individual child, left an indelible stamp on the educational reform movements of the later eighteenth and early nineteenth century, associated with such names as Pestalozzi and Froebel. ${ }^{1}$ His voice is still heard in contemporary educational discourse, whenever individual pupils' rights and freedoms, implied in such constructs as 'child-centred learning' or 'individual progess,' confront the collectivist forces of social interest.

Nowhere is the balancing of individual and societal 'needs' debated more fiercely than in modern Germany, where the history of educational 
reform has been described as one of 'social contradiction' (Friedeburg). The modern western principle of free universal education was established in post-reformation Saxony, and the European and North American models of secondary and higher education are rooted in the Prussian school reforms of the Napoleonic era. Yet despite, or perhaps because of, these historical achievements, child-focussed innovations in such areas as curriculum content and the integration of abilities, of the kind that have been applied with relatively little resistance in many western education systems, have found less favour within the Kultusministerien of the German Federal Republic. Those interested in the cultural connections of language and thought may suspect that the duality of needs which educational philosophers have laboured perennially to resolve is rendered particularly intransigent by a semantic differentiation in German, which distinguishes Bedürfnis, or needs that are identified and articulated by the subject, and Bedarf, or needs that require external validation.

Reconciling the legitimate needs of the child and of society was an important question for pedagogical theorists of the German Enlightenment - the Aufklärung - whose contribution to the history of educational ideas was not insignificant. The more prominent were strongly influenced by Rousseauist idealism. Notable among these were Johann Bernhard Basedow, sometimes looked upon as 'the father' of German educational reform, and Joachim Heinrich Campe. ${ }^{2}$ A lesser-known figure in this constellation is that of Ernst Christian Trapp (1745-1818), who is of historical interest, if for no other reason, as Germany's first professor of education. His brave attempts to erect a progressive yet pragmatic model of state education, beginning with the education of teachers, also merit more attention than they have received hitherto, at least in the English-speaking world. ${ }^{3}$ His attempted resolution of the issue of Bedürfnis and Bedarf in the education of the child was less radical than that of some of his contemporaries, but perhaps more firmly rooted in social and cultural reality.

Schooled in theology and the early Kant, Trapp was a Gymnasium administrator, who in 1772 became principle contributor for education to the Neue Allgemeine Deutsche Bibliothek, which under the editorship of Christoph Friedrich Nicolai was the most influential organ of the Aufklärung. On the recommendation of Campe, he joined Basedow's Philanthropinum; however Basedow was evidently an intemperate adminstrator, and Trapp was not alone in finding him impossible to work with (Bowen 200). ${ }^{4}$ A welcome opportunity to leave Dessau came from Prussia, where the first school reforms had been set in train by Frederick the Great's minister, Zedlitz. One of Zedlitz's initiatives was the establishment of an education faculty (Erziehungsinstitut) at the 
University of Halle, which opened in 1778 - coincidently the year of Rousseau's death - and was granted Germany's first chair of education the following year. On Nicolai's recommendation, Trapp received the call. The reform of teacher education was a logical first step in the reform of the schools, and Trapp had already devoted much thought to this aspect. In his essay 'Von der Nothwendigkeit, Erziehen und Unterrichten als eine eigne Kunst zu studiren' (1779) he argued the recognition of education as a university discipline (Versuch einer Pädagogik 5-12) an argument that continues today in some quarters. In 1780 he published his major contribution to the discipline, his Versuch einer Pädagogik, which is a systematic exposé of his pedagogical principles and proposals for curriculum reform. It is worth considering this document in its contemporary and historical context. First, however, Trapp's 'tribulations' as a pedagogical activist merit a brief narration, since they arose, partly from a certain personal lack of stamina, ${ }^{5}$ but also from an early instance of the 'social contradiction' which has proved particularly intransigent for German educational reform.

In Halle Trapp was opposed from the outset by the Faculty of Theology, where future teachers had traditionally been schooled in classical literature and the catechism. Perhaps because of such public opposition, Trapp's lectures were sparsely attended. In less than two years Zedlitz dismissed him for no stated reason other than that he was 'a foreigner who will not be missed. ${ }^{\prime 6}$ He then moved to Hamburg to direct one of Campe's progressive schools, which had six pupils and soon closed its doors, and thence to Brunswick as member of the 'Commission for school improvement' established by Duke Karl Wilhelm Ferdinand's minister, Hardenberg. ${ }^{7}$ Trapp, Campe and Johann Stuve, another noted figure in the philanthropic movement, constituted a Schuldirektorium mandated to assume control of the schools from the estates and church consistories. The inevitable power struggle underlines the fragility of the Enlightenment even in societies whose ruler (like Frederick the Great) claimed to support it. The Duke of Brunswick had secured the services of the greatest Aufklärer of them all, Gotthold Lessing, as Librarian in Wolfenbüttel. Yet when this triumvirate of pedagogues set forth its plans to improve teachers' training and working conditions, curriculum content, textbooks and methods, ${ }^{8}$ showing particular concern for peasantry and for girls, ${ }^{9}$ the cry went up that Christian schools had fallen into the hands of atheists. The Directorium was dissolved in 1790 and the schools restored to the control of the church and local gentry.

Thereafter Trapp confined his reform ideas to the pages of the journals he continued to edit, ${ }^{10}$ at first in Brunswick and later, following the conservative reaction to the French Revolution, from Denmark. His death in 1818 went largely unnoticed. However he was remembered 
with respect as late as 1833, in a tribute by the memoirist Friedrich Karl von Strombeck, who wrote:

It is not possible to conceive of a man more humane, benevolent, or disposed to service and sacrifice than Trapp ... Politically he was a republican, yet of moderate principles, who gratefully acknowledged in the excellent administration of Karl Wilhelm Ferdinand the ultimate goal of republicanism, which is the welfare of the whole. ${ }^{11}$

'Welfare of the whole' ('Wohl des Ganzen') aptly summarizes the underlying mission of Trapp's Versuch einer Pädagogik, four hundred pages of uneven style, ranging from the trivial to flights of lyricism, yet distinguished by their intellectual calibre from the pedantic teacher manuals typical of the time. ${ }^{12}$ Emerging from a wealth of practical advice on curriculum, methods and discipline are attempts to answer two fundamental questions of educational theory: how does the child acquire knowledge of the world? and how should the child be prepared for his/her future role within a predetermined social structure?

On the first question, Trapp adopts the empiricist position of Locke and others, that ideas enter the child's mind through the senses. Following the Scottish theologian Alexander Gerard, whose Essay on Genius (German translation, Leipzig 1776) is quoted frequently, ideas - 'concepts,' as modern developmental psychologists would call them - are either simple or complex, the former reducible to similarity, difference, and approximation, the latter to coexistence, causality, and order. The associative links between them, which account for development of the mind, are established and strengthened by habit and affect. The process can also be facilitated by experiential learning situations, in which an adult mentor can direct the child's observation towards conceptually higher levels, an intriguingly modern belief. ${ }^{13}$ While most of this is derivative, Trapp clearly espouses a more individualist view of child development than Locke. ${ }^{14}$ Allowance is made for a degree of autonomy and individual variance. Thus young children learn most effectively under conditions of play ('freien Spielraum,' 246). This observation, too, contributes to the modern appearance of some of Trapp's thinking. He also endorses learning through discovery rather than rote (86-88), describes what sounds somewhat like a 'whole-language' reading lesson, ${ }^{15}$ and suggests that other languages may be learned through subject content, 'immersion' in other words (336-39).

It is not the intent here to offer a detailed account of Trapp's curriculum and teaching methods, but rather to characterize his view of the learning process in relation to learner endowment. Where contemporary notions tended to discount children as individuals, seeing them as a 
more or less homogenous sub-species waiting to be civilized, Trapp remarks in a typical aphorism that they 'are cleverer than their teachers, only the latter have the consolation of knowing that they are more learned' (325). ${ }^{16}$ An interesting illustration of this respect for the variant characteristics and abilities, in particular the affective potential, of individual pupils occurs in the section on teaching literature. In a radical departure from the classical curriculum, Trapp considers that contemporary authors, notably Fielding, Richardson, or the young Goethe, are more likely to stir the aesthetic sensibilities of the young, and that denying them such access would be counterproductive:

The discord between teachers and pupils can be seen very clearly when it comes to works of taste and sentiment. It often happens that the teacher expounds on Horace while the pupils are secretly reading the Sufferings of Werther. If they are caught doing so they are punished. But one ought to read such books with them, and feel with them, then afterwards they would also read the ancients with us ... A schoolchild despises a teacher who despises Werther and such books; and a despised teacher can never form the heart of one who despises him. ${ }^{17}$

Education of the heart is acknowledged not only as a valid educational objective, but also as one not particularly amenable to authoritarian approaches. It recognizes a diversity of inner inclination, of preferences and perceptions. And yet, we cannot overlook the underlying expediency of what amounts to a temporary indulgence of the child's taste in literature, which becomes a means to an end, that of ultimate acceptance of the traditionally sanctioned literary fare. There is nothing to suggest a desire on Trapp's part to create a new generation of Stürmer und Dränger, their sensibilities at odds with the culture of the age, and his sceptical stance towards Rousseau remains to be noted.

On the one hand, this recognition of the child's unique individuality is significant for delineating the progressive aspects of Trapp's thinking, a recognition of subjectivity as an individual variable to be respected and harnessed, rather than stamped out. On the other, it poses something of a problem when it comes to the second question for educators, that of preparing the child for society.

To understand Trapp's thinking here we must begin with his premise on the ultimate purpose of education, which is to achieve the essentially eudaemonist goal of happiness, 'Glückseligkeit' (literally, 'blessedness through good fortune'). The preamble to the Versuch sees education as a 'Bildung des Menschen zur Glückseligkeit' ('formation of a human being for happiness,' 33). This formative process is later further refined as a 'Modifikation des Menschen in der Absicht ihn glücklich zu machen' ('modification of a human being to enable him to achieve happiness,' 265, 
my italics). Happiness, then, is not bestowed by birthright, but must be achieved, and this to a degree that is 'möglich und nöthig' ('possible and necessary,' 42). It has boundaries, which apparently are set by society: 'One should look not just to what can become of the individual by virtue of his nature but what must become of him in consideration of the society for which he is destined. ${ }^{, 18}$ Here, then, is Trapp's formulation of that duality of individual and society, which may be foundational to educational philosophy, beginning with Plato's directive to 'turn' the pupil's soul in the right direction, towards the light (Republic 750-51).

Not only does Trapp acquiesce in the idea that education is a socializing process, he also sees it as a 'natural' process ('natürlich'). The epithet carried authoritative weight in contemporary thinking; however, a study of the contexts suggests that in Trapp's case nature is understood more as a pragmatic than an idealistic construct. Natural education is one which 'das menschliche Leben im Kleinen nachmacht' ('imitates human life on a small scale,' 189). His proposals to teach by way of contemporary literature, practical experience, or object lessons from daily life, rest on their potential to reflect realities beyond the classroom walls. And there is no more compelling a manifestation of external reality than the structures of that society which the child must enter. The principle of Modifikation derives particular force from this belief. The child's innate disposition is either already inclined, or else it must be 'modified,' to fit its predictable social function. In either case the end result is a twofold 'welfare,' happiness all around, one presumes, since '[i]f one ... can establish in the youth to be educated . . . dispositions which are similar to or harmonize with their future occupations in society, one attends at one and the same time to the welfare of society and the individual welfare of the pupil. ${ }^{19}$

The dualism of Trapp's natural education is thus resolved through what amounts to a pedagogy of social conformity. Its most eloquent statement occurs, significantly perhaps, in a passage which takes issue with the leading voice of non-conformity, that of Rousseau, who had, as it were, written the book on Natural Education:

One travels best in human society by swimming downstream on that river that springs from existing laws, prevailing ideas, customs, habits and traditions. The truth of this is shown by the sad history of many worthy and unworthy men who have attempted the opposite. Who at this point does not think of Rousseau, the worthiest of them all? ${ }^{20}$

Trapp distances himself from Rousseau elsewhere. In a discussion of Émile's 'Confession of the Vicar of Savoie,' he claims that his own natural education is based on 'familiarization' rather than 'instruction' ('indoc- 
trination'?), since it seeks to induce the love of virtue from 'what is present and visible' rather than what is 'future and invisible. ${ }^{21}$ Primarily, what is present and visible to the child (or must be made so) is, in Trapp's view, provided by existing social norms rather than those that may be established by a hypothetical future citizenry endowed with the moral autonomy to reshape society. ${ }^{22}$

While Rousseauists may object that an individual born to freedom will not find happiness in filling an allotted function in a society whose forms and institutions have no legitimate foundation in nature, the intended beneficiaries of Trapp's reforms were that section of humanity not normally afforded the luxury of such quibbling, children of labourers and peasants, of whom he states: 'Der größte Theil der Menschen hat mittelmäßige Naturanlagen' ('the greatest part of humanity is of mediocre endowment,' 155). Here reside the qualities which society needs the most, namely: 'practical knowledge of socially useful skills,' ' diligence, pliablity, obedience, loyalty,' and a 'dutiful, cheerful and automatic execution of the functions of one's position or trade. ${ }^{23}$ Trapp believed compassionately that ordinary children could be taught to achieve greater happiness in life, despite its inequalities. Non-conformity, from a rationalist, eudaemonist perspective, engenders suffering, which is sufficient reason to avoid it. The Versuch, which after all was intended for the education of teachers, is hardly a manifesto for the restructuring of society. Yet judging from his private correspondence and the documentation associated with the Brunswick reforms, Trapp the man held quite radical views on contemporary social institutions. ${ }^{24}$

Freedom, though relativized by Trapp's pragmatic approach, is not totally extinguished, at least in the moral sense. Although externally bound by societal norms, children can attain a degree of inner emancipation through the exercise of their moral autonomy. In the early years they are to be permitted an 'illusion of freedom' ('Schein der Freiheit,' 208), the purpose of which is to enable them to experience connections between moral decisions and their consequences. Teaching by precept is thus replaced by what today would be called a cognitive approach, which presupposes the child's capacity to see purpose and meaning in received standards for right conduct. Trapp extends this principle to the learning of those virtues that rule or ought to rule the conduct of society in general, the principal one being tolerance (225-41). German literature's best known treatment of this popular theme of the Aufklärung, Lessing's Nathan der Weise, was published in the same year as Trapp's Versuch, where it occasions a rhapsodic burst soaring above his characteristic cerebral prose. There is an incongruous foretaste of Schiller's ode 'To Joy' in his description of tolerance as 
the most essential bond of human society ... the proffered hand of love which brings humanity together and dissolves and mediates the conflicts of brothers . .. the source of immeasurable joy that flows in upon us from our consciousness of exercising this virtue and from its effect on others, the benevolence it rouses in them towards ourselves. ${ }^{25}$

If tolerance is the highest virtue, teaching it, modern educators know, is the most difficult of tasks, since it requires an unlearning, a 'modification' in Trapp's terminology, of an egocentric world view. He is short on particulars as to how this should be done, but he does remain consistent in his principles. As with its own conduct, the child must be given opportunities to perceive the practical harmful consequences for society of unsubstantiated opinion, when directed towards individuals or groups (235). Likewise it must be enabled to witness the overall communal benefits, the proliferation of happiness, that flow from the mutual acceptance of differences.

To summarise thus far, as a learning being Trapp's child, as it enters the hands of the pedagogue, is somewhat more complex than Locke's. Trapp sees children as having unique individualities and initially unique ways of perceiving the world, which must be respected and harnessed in the educational process. Unlike Rousseau, however, Trapp makes a clear statement that the ultimate outcome is submission to societal norms. Despite these constraints, does the initial acceptance of individuality contribute anything to the pedagogical process itself, regardless of outcome? How, in other words, is the teacher to use the hitherto unsuspected resources that lie within the untapped recesses of the mind and soul of the child? Trapp's solution is a simple but quite revolutionary one: the teacher must know the child. In his view, 'the reason why we know children so little, is first that we never bother to do so and secondly that they conceal themselves, their actions, and their motives from us, out of fear. ${ }^{26}$ In order to break this vicious circle, the teacher must place himself in the situation of an observer; in other words, he must become an empiricist, learning his subject, in the same way as the subject learns the world, through the senses.

If the empiricist mode was already firmly established by Locke, Trapp considers practicalities of what can clearly be recognized as a scientific empiricism. The teacher's role approximates that of an anthropologist, requiring objectivity, 'a practised eye,' and an extensive knowledge of different species of humanity in general and children of all ages (64). Thus equipped, the pedagogue enters an intimate association with the pupil as the latter's guide and mentor, a relationship which reminds us superficially of Rousseau; however, unlike the teacher-pupil relationship in Émile, this relationship, intended for the regular classroom, is 
manipulative in nature. The teacher leads the youth, when he believes he is leading himself, when 'the slightest stirring of emotion, the feeblest awakening of an idea in the youth cannot occur without the teacher noticing it, without his having instigated it for a particular purpose'(my italics). ${ }^{27}$ This hidden dependency, the pre-programmed awakening of an individual's self-knowledge at the hands of a wiser mentor whose absence from the action is illusory, would make the educational novel, or Bildungsroman, a distinctively German genre.

Trapp, then, conceptualizes the teacher-pupil relationship as a combination of ethnography and planned intervention. What distinguishes his pedagogical approach from prevailing practices is its insistence that pedagogical rules derive from the objectively observable reality of the individual child rather than from untested preconceptions (80) - the classical empirical principle. He thus makes a powerful plea for the application of experimental psychology to the human sciences, whether ethics or politics (22), and contends that education could provide as rich a field for scientific research as medicine:

As long as the world exists, there will always be something left for the physician and the pedagogue to observe, and the wealth of experiences in both these sciences, which are so analogous and which I therefore mention here together without excluding many others, is capable of growth into eternity. ${ }^{28}$

With a side-swipe at the theologians who ruled contemporary education - as evidenced by his own career - he ascribes the corruption of the young, not to 'die verderbte menschliche Natur' or 'die Einblasungen des Satans' ('the corruption of human nature,' 'the whisperings of Satan,' 124-25), but to the failure to apply scientific empiricism to their upbringing. Here, then, is an early statement of a faith which has continued to sustain the theory and practice of education to the present day, leading to its eventual if anomolous acceptance into the ranks of the social sciences.

The empiricist's faith in observation is, of course, based on the most humane motives: respect for the distinctiveness of individuals, and fairness and objectivity in determining the most appropriate measures for their improvement. Yet how humane are these measures in their application? The question arises in consideration of Trapp's proposed design for a model classroom (165-74), which he adopted from his former teacher Martin Ehler, a philosophy professor at Kiel. It is based on the spatio-dynamic principle of restricting the direction of vision and interaction within the classroom to a multiplicity of two-way channels, between the teacher and individual pupils. The children are to be partitioned from one another in adjacent, enclosed cubicles, which are open 
only to the front. ${ }^{29}$ They are led into these at the beginning of the class and their desk-tops placed before them. High boards restrain them from touching or kicking each other - even from sexual misconduct. A row of steel spikes on each desk prevents them from leaving their enclosures at will. The spikes are covered with green cloth to discourage playing with them, but also to increase the fear element, since 'the hidden is more fearful than the visible' (168). Trapp quotes pages of this nonsense with evident approval, his only change being the provision of reading and writing necessities (172). What ensues is a teaching environment designed for the purest mode of observation and intervention, which offers, willy-nilly, the purest mode of control.

Trapp's classroom illustrates a real dilemma for what might be termed applied, particularly institutionally applied, rational humanism. That it is an inherited dilemma of our culture has been shown with devastating effect by Michel Foucault in Surveiller et punir, which documents the uses of observation in the prisons, asylums, and schools of Europe over the last two centuries. Through physical dispositions that became ever more restrictive and refined, culminating in Jeremy Bentham's plan for a prison which he called a Panopticon (1843), the prisoner, inmate, patient, or pupil could be subjected to perpetual observation by the warder/teacher. The ostensible result of this all-invasive knowledge-gathering, which left no aspect of the individual's daily life unnoted, was moral correction (modification?) of the socially unacceptable. Its reality was physical and moral control. One of its principles was what Foucault calls 'enclosure.' A good illustration is provided by a lecture on the evils of alcoholism delivered to the inmates of Fresnes prison in the early nineteenth century (Foucault, plate no. 8). The prisoners are physically separated from each other and constrained to face the speaker through narrow slots at the top of the perpendicular boxes in which they stand. This particular enclosure technique is one of 'partitioning,' to achieve 'disciplinary space,' that is, space that

tends to be divided into as many sections as there are bodies or elements to be distributed. One must eliminate the effects of imprecise distributions, the uncontrolled disappearance of individuals, their diffuse circulation, their unusable and dangerous coagulation; it was a tactic of anti-desertion, anti-vagabondage, anti-concentration. (Foucault 143)

The auditorium of Fresnes prison may not be so far removed from the humble country school room in which Trapp's ordinary child will be diagnosed and suitably modified for happiness in a world of rigid expectations. The relapse into an eighteenth- and early nineteenth-century obsession with controlling multitudinous bodies in order to shape 
the moral substance they house seems at odds with the belief sustained through much of the Versuch, that children can be reached and changed cognitively and affectively, through their understanding and sentiments. This is the underlying belief which marks the significant advance of Trapp's educational theory. In advocating Ehler's hen-battery of a classroom, one must assume he is saying that to reach and change the inner child one must first neutralize its innate unruliness, so that the sound principles of a natural (that is, pragmatic) education will yield their eventual fruits. This of course is the real dualistic dilemma facing all who teach for a given, rather than an imagined, world, those who labour to teach uniquely endowed individuals, in full knowledge and consideration of their uniqueness, yet for societies and within institutions that could not survive a day without their boundaries, rules, and expectations, their moral and physical constraints of every kind.

Germany's first professor of education, committed in his political and intellectual endeavours to Enlightenment goals of individual and communal happiness, was not immune to education's most bothersome dilemma, that of reconciling individualism and authority. Is there an alternative to embracing (Locke) or ignoring (Rousseau) established structures? Trapp at least attempts a middle way, proceeding from a psychologically sharpened view of the child and child development and a recognition of individual diversity. Enclosed within their classroom, as they will later be enclosed within their social class, children can still discover and preserve some valued inner part, that feels and sees diffently, even as the yoke of submission falls upon them. Versuch einer Pädagogik is of interest to educational historians and scholars of the Aufklärung alike. It is a worthy exponent of its sociocultural context, which deals with the same essential issues of purpose, process, and product that engage educational thinkers of any age. Perhaps it is a more honest document than those of other such thinkers.

NORMAN R. DIFFEY

University of Windsor 


\section{Notes}

1 In a Paris essay (1826) Pestalozzi hailed Rousseau as the 'centre de mouvement de l'ancien et du nouveau monde en fait d'éducation [qui] brisa avec une force d'Hercule les chaînes de l'esprit, en rendit l'enfant à lui-même, et l'éducation à l'enfant et à la nature humaine' (Thiéry 17).

2 Johann Bernhard Basedow (1724-90), whose famous primer for parents Das Elementarwerk appeared in two parts in 1770 and 1772 - and continued to be issued until 1909! — received his inspiration directly from Émile. He is best known as founder of the Dessau Philanthropinum, an experimental school which stressed practical and outdoor activities, a non-classical curriculum, and self-directed learning, and became the prototype for many such institutions throughout Europe. Joachim Heinrich Campe (1746-1818), also a member of the Philanthropinum, took an active role in the restructuring of the Brunswick school system (see above) and wrote many children's books, including an adaptation of Robinson Crusoe.

3 This impression is based on standard reference works. Bowen's chapter on Education and the Englightenment (168-202) deals mainly with Locke and Rousseau and adds a few pages on Basedow. Meyer lists him as a follower of Basedow and misspells his name (347). Interestingly, Meyer's review of the beginnings of modern German education attaches much significance to the founding in 1694 of the University of Halle, 'saluted in educational chronicles as the world's first modern university' (257). The irony here will become apparent.

4 See Trapp's letter to Prince Leopold von Anhalt-Dessau of 16 December 1771 (423).

5 Campe described Trapp as 'lacking in that physical size, strength and firmness which is needed by any one who must make an effect on others through his own person and without the external advantages of wealth and rank' ('... es fehlt ihm diejenige körperliche Größe, Kraft und Festigkeit, die derjenige, welcher persönlich, und zwar allein, und zwar ohne äußerliche Vorzüge der Gabe und des Standes, auf andere wirken soll, nothwendig haben muß ...' 430).

6 ‘Da er ein Ausländer ist, und ich auch dafür halte, daß sein Verlust nicht unersetzlich ist ...' (427).

7 Karl August von Hardenberg (1750-1822) later acquired fame as the Prussian statesman instrumental in the post-Napoleonic restructuring of Europe.

8 For an account of the Brunswick school reforms, see Friedeburg (42-46).

9 In 1786, Campe wrote: 'Käme ein Mondbürger herab auf unsere Erde . . . würde er in sein Tagebuch schreiben ... daß die zahlreichen Classen derjenigen Erdbewohner, welche ihre müßigen, verzehrenden und gebietenden Brüder füttern müssen, so dumm und viehisch als möglich bleiben ... und was das weibliche Geschlecht ... betrift, so scheint es den besagten Staaten gleichviel zu seyn, ob Menschen oder Meerkatzen daraus werden, so wenig bekümmern sie sich darum!' ('If a citizen of the moon came down to earth he would write in his journal that great masses of earth-dwellers are kept as stupid and bestial as possible while they nourish their idle, wasteful and tyrannical brethren, and as far as the female gender is concerned ... it seems a matter of indifference ... whether they become humans or monkeys, judging by the attention they are paid.') Quoted in Friedeburg (44). 
10 The Allgemeine Revision des gesamten Schul-und Erziehungswesens and the Braunschweigische Journal philosophischen, philologischen und pädagogischen Inhalts.

11 'Es ist nicht möglich, daß es einen humanern, wohlwollendern, stets zu Diensten und Aufopferungen bereitwilligern Mann geben kann, als Trapp war. ... In politscher Hinsicht war er ein Republicaner, doch mit den gemäßigsten Grundsätzen, und dankbar in der trefflichen Administration Karl Wilhelm Ferdinands das letzte Ziel des Republicanismus, Wohl des Ganzen, erkennend' (Versuch einer Pädagogik, biographical notes, 419).

12 For example, Friedrich Samuel Bock's Lehrbuch der Erziehungskunst zum Gebrauch für christliche Eltern und künftige Jugendlehrer ('for the use of Christian parents and future teachers of youth'), which appeared in the same year (Königsberg and Leipzig, 1780).

13 In the modern context, the name of Lev Vygotsky, one of the most prominent twentieth-century developmental theorists, has become associated with this interactive view of child mental development.

14 Locke's educational theory is best remembered for the universalist 'tabula rasa' image of the child's mind (stated at the beginning of Human Understanding) as 'white paper, or wax, to be moulded and fashioned as one pleases.' The image applies to the acquisition of ideas rather than to innate abilities and temperament. Locke intimates 'a primitive developmental-stage theory' and some awareness of individual variations; however his 'discussion of this aspect of educational procedure went no further and his model of the mind is almost entirely ontological rather than developmental' (Bowen 177).

15 Trapp proposes that the child should first associate the word with its meaning, then its overall shape, and finally its spelling (286). Traditional methods began with the alphabet (letter names followed by their sounds).

16 'Alle Schüler sind klüger, als ihre Lehrer; wobei aber doch diese den Trost haben, daß sie gelehrter sind, als alle ihre Schüler.' Elsewhere he remarks that 'much goes lost between our mouths and the children's ears.' ('Zwischen unserm Munde und den Ohren der Kinder geht Vieles verlohren,' 198).

17 'Die Mishelligkeiten zwischen Lehrer und Schüler zeigen sich sehr deutlich, wo es auf Werke des Geschmacks und der Empfindung ankömmt. Es geschieht wol, daß der Lehrer den Horaz erklärt, und die Schüler heimlich vor sich Werthers Leiden lesen. Sie werden bestraft, wenn man sie darüber ertappt. Aber man sollte dergleichen Bücher mit ihnen lesen und mit ihnen empfinden, so würden sie nachher auch mit uns die Alten lesen ... . Ein Schüler verachtet den Lehrer, der der Werther und dergleichen Bücher verachtet; und ein verachteter Lehrer kann nie das Herz dessen bilden, der ihn verachtet' (322-23).

18 'Man muß nicht bloß darauf sehen, was aus dem Menschen vermöge seiner Natur werden kann, sondern eben so sehr darauf, was aus ihm in Rücksicht auf die Gesellschaft, wofür er bestimmt ist, werden muß' (45).

19 'Wenn man ... solche Dispositionen in der zu erziehenden Jugend anlegen kann, mit denen ihre künftigen Beschäftigungen in der Gesellschaft gleichartig sind, oder harmoniren: so sorgt man zugleich für das Wohl der Gesellschaft, und für das individuelle Wohl des Zöglings' (158).

20 'Man fährt in der menschlichen Gesellschaft am besten, wenn man auf dem Strom hinunter schwimmt, den eingeführte Gesetze, herrschende Ideen, Sitten, Gewohnheiten und Gebräuche in Gang gebracht haben. Daß dis wahr sei, beweist die traurige 
Geschichte vieler würdigen Männer, die das Gegenteil versucht haben. Wem wird hier nicht Rousseau, als der würdigste, einfallen?' (135, original emphases).

21 '... mehr aus dem Gegenwärtigen und Sichtbaren, als aus dem Zukünftigen und Unsichtbaren Bewegungsgründe und Reiz zur Tugend hernähme ...'(236)

22 Émile is 'a harbinger of Nietzsche's superman,' according to Bloom (93). Rousseau's disdain for social reality in the formulation of his educational theory is noted by René Pomeau (Thiéry 4). A more pragmatic approach would, in Rousseau's view, have amounted to collaborating with existing evil ('s'allier avec le mal existant').

23 '. . a alle praktische Kenntnisse gemeinnütziger Wissenschaften . . . Arbeitsamkeit, Lenksamkeit, Gehorsam, Treue, pflichtmäßiger, unverdroßener und mechanischer Gang in den Geschäften des Amts und Berufs ...' (156)

24 See biographical notes in Trapp (430-33) for evidence of his growing anti-monarchist sentiments in the wake of the Prussian reaction to the French Revolution, with its new curbs on the press and official repudiation of the Aufklärung.

25 'Die Toleranz ... ist das unentbehrlichste Band der menschlichen Gesellschaft; ist die ausgestreckte Hand der Liebe, um den Bruder zu sich zu ziehn, um streitende Brüder von einander zu halten und zu versöhnen; ist die Quelle unzähliger Freuden, die aus dem Bewußtsein, diese Tugend zu üben, und aus ihrer Wirkung auf andere, durch die in ihnen dadurch erregte Gesinnung gegen uns, auf uns hinfließen' (225-26).

26 'Daß wir die Kinder so wenig kennen, kömmt, ausser der Ursache, daß wir uns keine Mühe darum geben, auch daher, daß sie sich und ihre Handlungen und ihre Bewegursachen aus Furcht vor uns verbergen' (69)

27 '... wo die leiseste Anregung einer Empfindung, die schwächste Erweckung einer Idee in dem Zögling nicht geschehen kann, ohne daß der Lehrer sie merke, ohne daß er sie, zu einem gewissen Zweck, veranstaltet habe ...'(125)

28 'So lange die Welt steht, wird immer für den Arzt und den Pädagogen etwas zu beobachten zu bemerken übrig bleiben und der Schatz der Erfahrungen in diesen beiden Wissenschaften, die so sehr analogisch sind, und die ich deswegen hier zusammen nenne, ohne manche andere auszuschließen, ist eines Wachstums ins Unendliche fähig' (62).

29 Two readers of this paper have independently remarked on the similarity between this arrangement and a modern language laboratory, an interesting observation since the latter is based on a behavioristic learning theory of habit modification. Both diminish the interactive nature of learning, which Trapp appears to advocate, as noted earlier, to some degree. 


\section{Works Cited}

Bloom, Allan Bloom. Love and Friendship. New York: Simon and Schuster, 1993.

Bowen, James. A History of Western Education. 3 vols. London: Methuen, 1981. Volume Three: The Modern West: Europe and the New World.

Foucault, Michel. Discipline and Punish: The Birth of the Prison. Trans. A. Sheridan. London: Penguin, 1977. Trans. of Surveiller et punir, 1975.

Friedeburg, Ludwig von. Bildungsreform in Deutschland: Geschichte und gesellschaftlicher Widerspruch. Frankfurt: Suhrkamp, 1989.

Locke, John. Some Thoughts Concerning Education. Ed. John W. and Jean S. Yolton. Oxford: Clarendon, 1989.

Meyer, Adolphe E. An Educational History of the Western World. New York: McGraw-Hill, 1965.

Plato. Republic. Trans. Paul Shorey. The Collected Dialogues of Plato. Ed. E. Hamilton and H. Cairns. Princeton: University Press, 1961.

Rousseau, Jean-Jacques. Émile ou de l'éducation. Ed. F. \& P. Richard. Paris: Garnier, 1964.

Thiéry, Robert (ed.). Rousseau, l'Émile et la révolution: Actes du colloque international de Montmorency, 27 septembre-4 octobre 1989. Paris: Universitas, 1992.

Trapp, Ernst Christian. Versuch einer Pädagogik, Unveränderter Nachdruck der 1. Ausgabe Berlin 1780. Ed. Ulrich Herrmann, Paderborn: Schöningh, 1977. 